\title{
Variations in bacterial community structure during a dinoflagellate bloom analyzed by DGGE and 16S rDNA sequencing
}

\author{
Laura B. Fandino*, Lasse Riemann**, Grieg F. Steward***, Richard A. Long, Farooq Azam \\ Marine Biology Research Division, Scripps Institution of Oceanography, 8750 Biological Grade, San Diego, \\ California 92037-0202, USA
}

\begin{abstract}
The relationship between bacterial 16S rRNA gene composition and carbon metabolism was analyzed during an intense dinoflagellate bloom off the Southern California coast during the spring of 1997. Bacterial numbers and rate processes, chlorophyll $a$, and the dissolved and particulate organic matter pools were measured during the bloom to provide a framework within which to assess bacterial community composition. Free bacteria were numerically dominant, generally comprising $>90 \%$ of the total, and were responsible for $>70 \%$ of bacterial production. Attached bacteria had higher cell-specific growth rates than free bacteria (range $=0.5$ to 15.1 and 0.7 to $2.5 \mathrm{~d}^{-1}$, respectively) and had hydrolytic ectoenzyme activities at times more than an order of magnitude higher on a per cell basis. Denaturing gradient gel electrophoresis analysis of bacterial community composition indicated that: (1) the free and attached communities were distinct, and (2) marked shifts in bacterial community structure occurred concomitant with the peaks in attached enzyme activities, specific growth rates and DOC concentration. Of the 24 16S rDNA clones analyzed, 7 were related to the Cytophaga-like bacteria (CLB), 6 to the $\alpha$-subclass and 5 to the $\gamma$-subclass of the Proteobacteria; 3 were related to oxygenic phototrophs, 2 were heteroduplexes and 1 was a possible chimera. While the $\alpha$ - and $\gamma$-Proteobacteria predominated in the $<1.0 \mu \mathrm{m}$ fraction, CLB were identified in both the free and attached fractions as well as among bacteria cultured from the same water, without overlap among these groups. The observation that distinct Cytophaga group sequences were present in the free versus attached fractions is counter to the current understanding that these organisms occupy a principally 'particle-specialist' niche. Our results suggest that some CLB are also important in the decomposition of polymeric organic matter in the dissolved phase with implications for the accumulation of dissolved organic matter and pathways of carbon flow during phytoplankton blooms.
\end{abstract}

KEY WORDS: Bacteria $\cdot$ Community composition · DGGE $\cdot$ Cell-specific activity $\cdot$ Algal bloom

Resale or republication not permitted without written consent of the publisher

\section{INTRODUCTION}

Bacteria are ubiquitous members of marine plankton communities and play critical roles in determining the fate of carbon and nutrients in aquatic systems. Despite their biogeochemical importance, variations in bacterioplankton community structure are not well

\footnotetext{
*E-mail: lfandino@ucsd.edu

Present addresses:

${ }^{* *}$ Freshwater Biological Laboratory, University of Copenhagen, 51 Helsingørsgade, 400 Hillerød, Denmark

***Department of Ocean Sciences, University of California, 1156 High Street, Santa Cruz, California 95064, USA
}

understood. 16S rDNA sequencing tools applied to environmental samples have shown that the composition of microbial communities is not static but changes with depth (Giovannoni et al. 1996), season (Rehnstam et al. 1993) and in different macro- (Murray et al. 1996) and microenvironments (DeLong et al. 1993, Bidle \& Fletcher 1995). Such studies typically provide rough genotype inventories of bacterial communities but the relationship between bacterial community structure and net community metabolism is, at present, unknown. A current challenge is to relate changing bacterial genotype and associated phenotype dominances with variations in organic matter utilization and remineralization. 
Shifts in bacterial community structure may be important to carbon and nutrient flows in the ocean through impacts on net heterotrophy. Organic matter utilization by bacteria depends in part on the activity of ectohydrolytic enzymes, but enzyme profiles of microbial consortia (Smith et al. 1992) and individual isolates (Martinez et al. 1996) vary widely. Martinez et al. (1996) found that 44 marine bacterial isolates surveyed displayed different enzyme profiles and suggested that the rate and extent of polymer and particle hydrolysis in the sea may depend on bacterial community composition. Differences in ectoenzyme expression, bacterial secondary production and growth rates in phylogenetically uncharacterized microbial assemblages have also been found to differentiate particles-associated from free-living bacterial communities (Smith et al. 1995). DeLong et al. (1993), additionally, found that particle-associated marine bacterial communities may be genotypically distinct from those in the surrounding water. The implication of these studies is that changes in the composition of bacterial communities may cause differential transformation of the organic matter field. We investigated this hypothesis during a bloom of the dinoflagellate Lingulodinium polyedrum by asking whether changes in bacterial rate processes (growth rates and ectoenzymatic activities) are associated with changes in community composition or changes in percell gene expression.

The Lingulodinium polyedrum bloom provided an opportunity to follow bacterial phylotype changes over a wide range of particulate and dissolved organic carbon (POC and DOC) concentrations. Attached and free-living bacterial communities were analyzed by denaturing gradient gel electrophoresis (DGGE) profile analysis of $16 \mathrm{~S}$ rRNA gene fragments. Bacterial and phytoplankton standing stocks, bacterial rate processes, and POC and DOC concentrations were measured to provide a context for the analysis of bacterial community composition. Our specific questions were (1) Do shifts in 16S rDNA composition co-occur with the metabolic response of the bacterial community to changes in organic matter? (2) Are the free and attached populations distinct? and (3) Do bacteria cultivated during the bloom overlap with the 16S rDNA sequences identified by direct cloning and sequencing?

\section{MATERIALS AND METHODS}

Sample collection. Seawater samples were collected from the end of the pier at the Scripps Institution of Oceanography $\left(32^{\circ} 52^{\prime} \mathrm{N}, 117^{\circ} 15^{\prime} \mathrm{W}\right)$ at approximately $0.5 \mathrm{~m}$ depth between 13:00 and 15:00 h. Collection was conducted every 1 to $3 \mathrm{~d}$ during the period of 30 April to 30 May 1997, and then approximately weekly until the end of June 1997 for analyses of carbon dynamics. Seawater samples for DNA extraction were collected over a time course on the following dates: 5 May, 7 May, 9 May, 13 May, 30 May, 9 June, 25 June. This period encompassed both the peak and decline in bacterial and algal biomasses associated with the dinoflagellate bloom. Daily sea surface temperature (SST) and salinity data were obtained courtesy of John McGowan and Connie Fey (Data Report, University of California, San Diego, California, 1916-1997).

Seawater samples for bacterial DNA isolation ( 7 to 10 l) were filtered sequentially through glass fiber filters (Gelman Sciences, type A/E, $142 \mathrm{~mm}$ diameter) and $0.22 \mu \mathrm{m}$ pore size, pleated Pall Gelman culture capsules (Gelman Sciences) at a pressure $\leq 25 \mathrm{~mm} \mathrm{Hg}$. Both capsules and pre-filters were stored at $-80^{\circ} \mathrm{C}$ until processed. Multiple pre-filters were used, as needed, depending on the concentration of particulate matter within seawater samples. Bacteria collected on the glass fiber filters $(1.0 \mu \mathrm{m}$ nominal pore size) were operationally defined as particle-associated while those passing through the glass fiber filter, but retained by the capsule filter, were defined as freeliving. Unfiltered and gravity-filtered (glass fiber filter; Whatman type GF/C) seawater was also collected for measurements of bacterial and dinoflagellate abundances, bacterial carbon production (BCP), bacterial enzyme activities, POC and DOC, and chlorophyll a (chl a). The contribution of particle-associated bacteria to carbon flux during the bloom was estimated as the difference between measurements on unfiltered and filtered seawater. Bacteria were isolated by spreading $100 \mu \mathrm{l}$ of unfiltered or filtered seawater onto duplicate plates of ZoBell 2216E medium (5 g peptone, $1 \mathrm{~g}$ yeast extract, 15 g Bacto-Agar per liter GF/F filtered seawater; without iron addition). Clonal isolates were obtained by serially streaking individual colonies 3 times on the same medium.

Chl a and organic carbon. Seawater was filtered in duplicate on glass fiber filters (Whatman type GF/F) for chl a extraction and stored at $-20^{\circ} \mathrm{C}$ in the dark until processed. Filters were extracted with $96 \%$ ethanol overnight in the dark at $20^{\circ} \mathrm{C}$ and chl a concentration was determined spectrophotometrically by the method of Jespersen \& Christoffersen (1987). POC was analyzed by filtering duplicate 50 to $200 \mathrm{ml}$ seawater samples through precombusted Whatman type GF/F filters; filters were folded in half, wrapped in aluminum foil and stored frozen until processed on a Perkin Elmer Model $2400 \mathrm{C} / \mathrm{H} / \mathrm{N}$ analyzer. For DOC analysis, subsamples of POC filtrate were collected in duplicate precombusted glass ampoules and frozen until analysis on a Shimadzu 5000A TOC analyzer (Sugimura \& Suzuki 1988). 
Cell counts and bacterial rate processes. Bacterial abundance, BCP and ectoenzyme activities were analyzed for both unfiltered and $<1.0 \mu \mathrm{m}$ filtered samples to characterize attached and free bacterial activities during the bloom. Bacterial abundance was quantified by epifluorescence microscopy direct counts (Porter \& Feig 1980) on samples fixed with borate-buffered formalin ( $2 \%$ final concentration) and stained with DAPI (4',6-diamidino-2-phenylindole; $1 \mathrm{\mu g} \mathrm{ml}^{-1}$ final concentration). Autofluorescing Lingulodinium polyedrum cells were quantified in the same samples using blue light excitation. At least 20 frames or 200 cells were counted per sample, with replicate slides counted on approximately two-thirds of the dates sampled. Only unfiltered seawater was analyzed on 30 April and 6 May.

BCP was estimated from the incorporation of ${ }^{3} \mathrm{H}$ leucine (Kirchman et al. 1985, Simon \& Azam 1989) using the centrifugation protocol of Smith \& Azam (1992). Additional cellular productivity estimates based on ${ }^{3} \mathrm{H}$-thymidine incorporation (Fuhrman \& Azam 1982) were used to derive bacterial specific growth rates $(\mu)$ assuming $20 \mathrm{fg} \mathrm{C}^{\mathrm{C}}$ bacterium ${ }^{-1}$ and exponential growth (Lee \& Fuhrman 1987). Both ${ }^{3} \mathrm{H}$-leucine and ${ }^{3} \mathrm{H}$-thymidine production estimates were measured in triplicate with $5 \%$ trichloroacetic acid-killed samples serving as blanks. Bacterial production was not analyzed in size-fractionated water on 30 April and 2 May; hence, only total production values are reported on these dates.

Extracellular enzyme activities were measured for all samples from the rate of hydrolysis of fluorogenic substrate analogues (Hoppe 1983) using a Hoefer TKO-100 fluorometer (356 nm excitation, $460 \mathrm{~nm}$ emission). All samples were incubated in triplicate with boiled samples serving as controls. The fluorogenic substrates assayed were L-leucine-4-methylcourmarinyl-7-amide (Leu-AMC) to analyze protease activity; and the 4-methylumbelliferone (MUF) substrates: MUF- $\alpha$-Dglucoside, MUF- $\beta$-D-glucoside, and MUF-phosphate to analyze $\alpha$ - and $\beta$-glucosidase and phosphatase activities, respectively.

DNA isolation and quantification. DNA isolation from natural mixed microbial populations was modified from Fuhrman et al. (1988). Particle-associated bacterial DNA was not obtained for 2 of the sampling dates due to the contamination of these pre-filters. The retentate was gently washed from thawed pre-filters with STE buffer $(100 \mathrm{mM} \mathrm{NaCl}, 10 \mathrm{mM}$ Tris hydrochloride [pH 8], $1 \mathrm{mM}$ EDTA), collected in $50 \mathrm{ml}$ conical centrifuge tubes, and concentrated by filtration onto $47 \mathrm{~mm}$ diameter, $0.2 \mu \mathrm{m}$ pore size polycarbonate (PC) filters. The PC filters were then placed into conical $50 \mathrm{ml}$ polypropylene centrifuge tubes containing $4 \mathrm{ml}$ STE buffer and vortexed to release captured bacteria.
Bacterial cells were lysed by the addition of $1 \%(\mathrm{w} / \mathrm{v}$ final concentration) sodium dodecyl sulfate (SDS) and incubated for $5 \mathrm{~min}$ in a boiling water bath. Free-living bacterial community DNA, i.e. the $<1.0 \mu \mathrm{m}$ fraction, was isolated from thawed Gelman capsules. Bacterial cells trapped on the capsule filter were lysed by adding $20 \mathrm{ml}$ of hot STE buffer containing 1\% SDS. Capsules were incubated for 5 to $7 \mathrm{~min}$ in a boiling water bath with continuous rotation. Lysate was collected in $50 \mathrm{ml}$ polypropylene centrifuge tubes. Subsequent steps of DNA purification followed Fuhrman et al. (1988) and purified DNA was quantified fluorometrically with the PicoGreen dsDNA quantification kit (Molecular Probes, Eugene, Oregon).

Polymerase chain reaction, DGGE and cloning. Changes in bacterial community structure were analyzed by polymerase chain reaction (PCR) amplification of a portion of the bacterial 16S rRNA gene followed by DGGE and sequencing. 16S rRNA genes were amplified in triplicate $100 \mu \mathrm{l}$ reactions using 50 ng of community DNA and AmpliTaq Gold DNA polymerase (Perkin Elmer). The primer pair used complements Escherichia coli positions 341-358 (plus GC clamp) and 517-534, generating a ca $191 \mathrm{bp}$ fragment (Muyzer et al. 1993). The hot start and the touchdown annealing reaction conditions (annealing temperatures declining from 60 to $53^{\circ} \mathrm{C}$ ) and reaction reagents have been described in detail previously (Don et al. 1991, Teske et al. 1996). Amplification products were checked by electrophoresis on $5 \%(\mathrm{w} / \mathrm{v})$ polyacrylamide gels. Gels were stained with SYBR Green I (Molecular Probes) and visualized with UV transillumination. The remaining DNA from triplicate amplifications was pooled and concentrated by ethanol precipitation (Sambrook et al. 1989) using 1/10 volume of $10 \mathrm{M} \mathrm{LiCl}$ in place of $5 \mathrm{M} \mathrm{NaCl}$. DNA concentration was quantified fluorometrically with PicoGreen.

The DGGE techniques and reagents used here were described by Muyzer et al. (1993) with a few amendments to optimize the protocol for these samples. The denaturing gradient concentrations best suited for amplicon separation were empirically determined to be 25 to $50 \%$ (100\% denaturant is $7 \mathrm{M}$ urea, $40 \%$ [v/v] formamide). Amplicon concentrations were normalized (800 $\mathrm{ng}$ ) per lane to allow comparison of relative banding patterns and intensities between samples. Electrophoresis was performed on $8 \%$ polyacrylamide gels in $0.5 \times$ TAE buffer, under constant voltage $(10 \mathrm{~V}$ $\mathrm{cm}^{-1}$ ), for $6.0 \mathrm{~h}$ at $60^{\circ} \mathrm{C}$ in a hot bath aquarium (CBS Scientific Co.). Following electrophoresis, the gels were stained with SYBR Green I and were photographed using UV transillumination.

Single bands containing 16S rDNA fragments were excised from the DGGE gel with sterile razor blades and placed in individual sterile $2.0 \mathrm{ml}$ microcentrifuge 
tubes. DNA was eluted from the gel fragment in $500 \mu \mathrm{l}$ of $1 \times \mathrm{SSC}$ overnight at $37^{\circ} \mathrm{C}$ followed by LiCl/ethanol precipitation. Isolated $16 \mathrm{~S}$ rRNA gene fragments were cloned into the plasmid vector PCR2.1 as described by the manufacturer (Invitrogen). The presence of cloned inserts was checked either by EcoR1 restriction digestion of purified plasmid DNA or by amplification of the insert from the plasmid using the amplification conditions described above. PCR amplification and DGGE analysis of the vector insert were used to confirm the position of the cloned sequences and to check for heteroduplexes (Ferris et al. 1996). Non-heteroduplex inserts were sequenced using M13 vector primers and dye-terminator chemistry on an Applied Biosystems automated sequencer. Second strand sequencing was performed using a second clone to confirm the results of the cloning and sequencing steps.

Colony-blot hybridization. Sixty-seven bacterial isolates collected during the bloom were placed in a grid pattern on ZoBell plates. The isolates were chosen based on differences in colony morphology so that phenotypically distinct types (based on colony color, size and shape) were represented at least once. Members of the Cytophaga-Flavobacterium-Bacteroides lineage were identified by colony hybridization using a ${ }^{32} \mathrm{P}$ end-labeled probe (CF319a) specific for $90 \%$ of the group (Manz et al. 1996). Colonies were transferred to duplicate nylon membranes and all subsequent steps of colony lysis and hybridization followed Sambrook et al. (1989). Pre-hybridization was conducted for $4 \mathrm{~h}$ at $55^{\circ} \mathrm{C}$ followed by an overnight hybridization with the addition of $1 \times$ $10^{6} \mathrm{cpm}$ probe per $\mathrm{ml}$ of hybridization solution. Marine Cytophaga group isolates previously identified in our laboratory were used as positive controls and Escherichia coli was used as a negative control. 16S rDNA fragments were PCR amplified using the GC-341F/534R primer pair from the 8 isolates that hybridized to the probe. The relative positions of these amplicons were compared by DGGE to identify unique types. Five different isolates were identified and the $16 \mathrm{~S}$ rDNA sequences of these were PCR amplified using the primer pair $27 \mathrm{~F}$ and 1492R (Weisburg et al. 1991) followed by direct sequencing as described above.

Data analyses. 16S rDNA sequence analysis was performed using Sequencher version 3.1 (Gene Codes Corporation) software, and sequences were aligned using the Ribosomal Database Project (RDP; Maidak et al. 1997) and BLAST (Altschul et al. 1990) network services. All sequences were submitted to the RDP program CHECKCHIMERA to identify possible chimeras within the $16 \mathrm{~S}$ sequences. A multiple sequence alignment was performed using the program CLUSTALW (Thompson et al. 1994) on the Internet (http://www.clustalw.genome.ad.jp/), and phylogenetic relationships were inferred by the neighbor-joining method using the Phylogenetic Inference Package (Phylip, version 3.4; Felsenstein 1993). The phylogenetic tree was constructed with the program Treeview (Page 1996).

The brightness of bands on the DGGE gel relative to the integrated pixel intensity per lane was calculated using scanned gel images and ONE-Dscan Eval version 2.2.4 software (Scanalytics, Inc.) for 1-dimension density analyses. Processed gel images were used to produce a matrix of normalized pixel intensity values per location on the gel. Values that fell below the minimum per-gel detection limit were omitted. These data

Table 1. The relationship of 16S rDNA sequences obtained from DGGE bands and Cytophaga group isolates to sequences in the RDP database (percent similarity to the closest relative is given in parentheses)

\begin{tabular}{|c|c|c|c|}
\hline $\begin{array}{l}\text { DGGE } \\
\text { band }\end{array}$ & Closest relative & $\begin{array}{l}\text { Isolate/clone } \\
\text { name }^{\mathrm{a}}\end{array}$ & $\begin{array}{l}\text { GenBank } \\
\text { accession no. }\end{array}$ \\
\hline 1 & SAR125 (93\%) & SCR1 & AF125347 \\
\hline 2 & Heteroduplex & - & - \\
\hline 3 & Heteroduplex & - & - \\
\hline 4 & Cytophaga sp. (93\%) & SCR2 & AF125346 \\
\hline 5 & FL1 (100\%) & $\mathrm{SC}$ & AF125345 \\
\hline 6 & Flavobacteria sp. (94\%) & $\mathrm{SC}$ & AF125344 \\
\hline 7 & Sphingomor & SCR5 & AF125343 \\
\hline 8 & Cytophaga sp. (97\%) & SCR6 & AF125342 \\
\hline 9 & $\alpha$-Proteobactel & $\mathrm{SC}$ & 1 \\
\hline 10 & SAR83 (92\%) & $\mathrm{SC}$ & AF125 \\
\hline 11 & Roseobacter litoralis (93\%) & SCR9 & AF125339 \\
\hline 12 & Chimera & - & - \\
\hline 13 & Marinobacter sp. & SCR10 & AF125338 \\
\hline 14 & SAR116 (100\%) & SCR11 & $\mathrm{AF}$ \\
\hline 15 & Roseobacter litoralis (93 & SCR9 & $\mathrm{AF} 125339^{\mathrm{c}}$ \\
\hline 16 & Cytophas & ATT1 & AF125328 \\
\hline 17 & SAR125 $(94 \%)$ & ATT2 & AF125329 \\
\hline 18 & aera sp. $(100 \%)$ & ATT3 & AF125330 \\
\hline 19 & $(100 \%)$ & ATT4 & AF125331 \\
\hline 20 & Cytophag & ATT5 & AF125332 \\
\hline 21 & sp. $(98 \%)$ & ATT6 & AF125333 \\
\hline 22 & Flexi & ATT7 & AF125334 \\
\hline 23 & Cytophaga sp. (95\%) & ATT8 & AF125335 \\
\hline 24 & Roseobacter litoralis (94\%) & ATT9 & AF125336 \\
\hline- & Cytophaga isolate (97\%) & LB1 & AF125323 \\
\hline- & Cytophaga isolate (97\%) & LB2 & AF125324 \\
\hline- & Cytophaga isolate (96\%) & LB3 & AF125325 \\
\hline- & Cytophaga isolate (96\%) & LB4 & AF125326 \\
\hline- & Cytophaga isolate (94\%) & LB5 & AF125327 \\
\hline \multicolumn{4}{|c|}{$\begin{array}{l}{ }^{\mathrm{a}} \text { The prefixes SCR and ATT refer to sequences from the free } \\
\text { and attached bacterial assemblages, respectively. The prefix } \\
\text { LB denotes Lingulodinium bloom Cytophaga group isolates }\end{array}$} \\
\hline \multicolumn{4}{|c|}{$\begin{array}{l}{ }^{\mathrm{b}} \text { Genbank accession numbers for sequences obtained in this } \\
\text { study }\end{array}$} \\
\hline \multicolumn{4}{|c|}{${ }^{\mathrm{C}}$ This sequence is identical to band 11 (SCR9) } \\
\hline
\end{tabular}


were used for Cluster analysis (1-Pearson $r$ distance; UPGMA) using Statistica version 5.1 software (StatSoft). Finally, correlation analyses of bacterial and phytoplankton standing stocks were conducted using the Spearman rank approach for non-normally distributed data with the software Statview (SAS Institute, Inc.).

GenBank accession numbers. 16S rRNA gene sequences from clones and Cytophaga group isolates were deposited in GenBank under accession numbers AF125323-AF125347 (Table 1).

\section{RESULTS}

\section{The bloom}

All parameters were measured between 30 April and 25 June during an intense Lingulodinium polyedrum bloom. Bloom intensity was indicated by changes in chl a concentration (2.0 to $166.4 \mu \mathrm{g} \mathrm{l}^{-1}$; Fig. $1 \mathrm{~A}$ ) and $L$. polyedrum cell counts $\left(0.2\right.$ to $31 \times 10^{5}$ cells $\mathrm{l}^{-1}$; data not shown). We have identified 2 broad phases of the bloom for ease of discussion. Phase 1 (30 April to 14

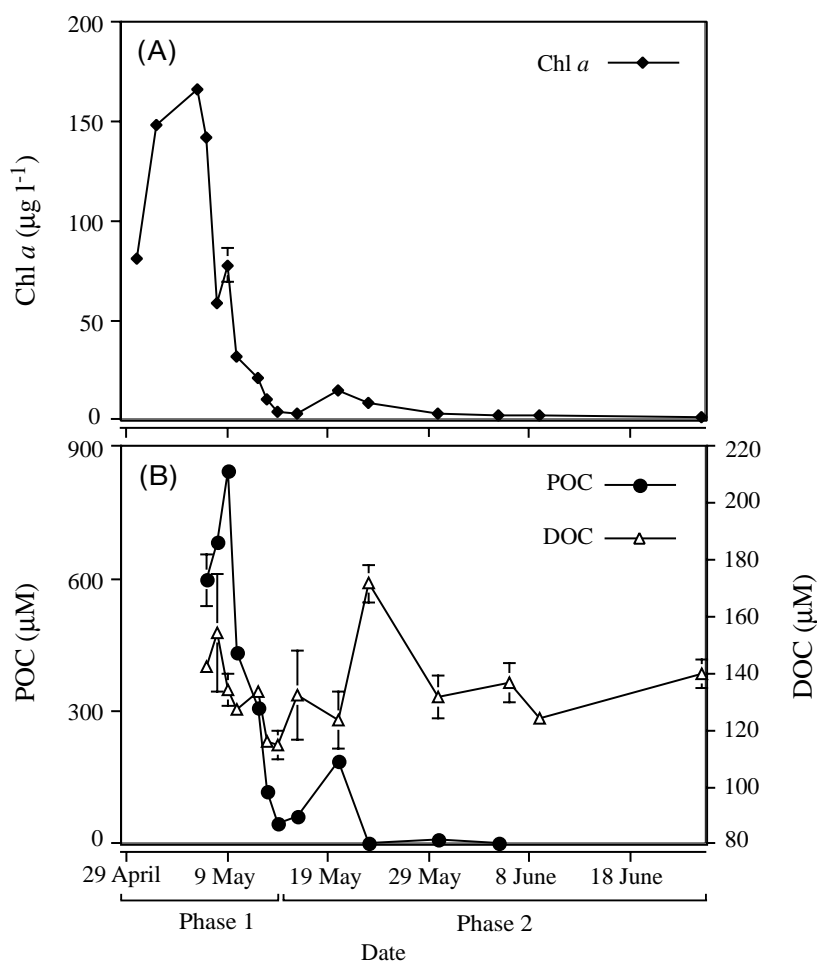

Fig. 1. Time course of (A) chl $a$ and (B) particulate (POC) and dissolved (DOC) organic carbon \pm SD during and after the bloom. POC values from single samples are reported on 8, 9, 12, and 13 May; in other instances, error bars, where not seen, fall within the symbols. Phases 1 and 2 of the bloom are shown for ease of reference
May) encompasses the period of maximum algal bio-

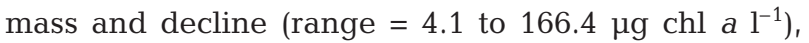
while Phase 2 encompasses the entire post-bloom period (range $=3.1$ to $14.8 \mu \mathrm{g} \mathrm{chl} \mathrm{a}{ }^{-1}$ ). During Phase 1, the chl a peak was associated with a $2.3^{\circ} \mathrm{C}$ increase in SST from 18.1 to $20.4^{\circ} \mathrm{C}$ between 4 and 6 May (data not shown). SST during the sampling periods otherwise remained relatively stable, with mean temperatures of $18.9 \pm 0.6$ and $20.8 \pm 0.4^{\circ} \mathrm{C}$, before and after the temperature increase, respectively. Only minor changes in salinity were observed $(33.8 \pm 0.05)$.

\section{Organic carbon}

POC concentrations ranged from $46.7 \pm 13.3 \mu \mathrm{M}$ to peak levels of $845.8 \pm 0.2 \mu \mathrm{M}$ during Phase 1 . The POC levels during Phase 2 (0.83 to $189.2 \mu \mathrm{M}$ ) included a second minor peak in POC on 20 May coincident with a small increase in chl a. Due to incomplete drying of some of the filters, duplicate POC measurements at some sample time points $(8,9,12$, and 13 May) showed a discrepancy of over an order of magnitude. To weed out erroneous measurements, chl a data were used to constrain all POC values (using a carbon:chl a ratio of 50; Redalje 1983). At each of these time points, one of the duplicates agreed with the chl a-based POC estimates and the others were discarded. These single measurements are included in Fig. 1B without error bars. Using a carbon:chl a ratio of 50, phytoplankton biomass accounted for $99 \%$ of POC at the chl a peak and between 20 and $38 \%$ of POC for the rest of the sampling period when detritus particulates comprised the bulk of the POC (data not shown). DOC concentrations during the bloom ranged from 115.0 to $171.7 \mu \mathrm{M}$ with the maximum value occurring on 23 May (Fig. 1B).

\section{Bacterial abundance, production and specific growth rates}

The abundance of free and attached bacteria is plotted versus time in Fig. 2A. Free-living bacteria generally comprised $>90 \%$ of the total abundance. The maximum bacterial abundance during Phase 1 was more than 2-fold higher than peak abundance during Phase 2 (ranges of 1.3 to 6.9 and 1.21 to $3 \times 10^{9}$ cells $\mathrm{l}^{-1}$ during Phases 1 and 2, respectively). Total bacterial numbers showed a strong correlation to chl $a(p=0.001)$.

Changes in BCP and bacterial-specific growth rates versus time are shown in Fig. 2B,C. Free-living bacteria were generally responsible for $>70 \%$ of the $\mathrm{BCP}$ (BCP ranges were 5.9 to 106.1 and 12.7 to $56.1 \mu \mathrm{g} \mathrm{C} \mathrm{l}^{-1}$ for Phases 1 and 2, respectively), with the date of maximum total production coinciding with maximum total 


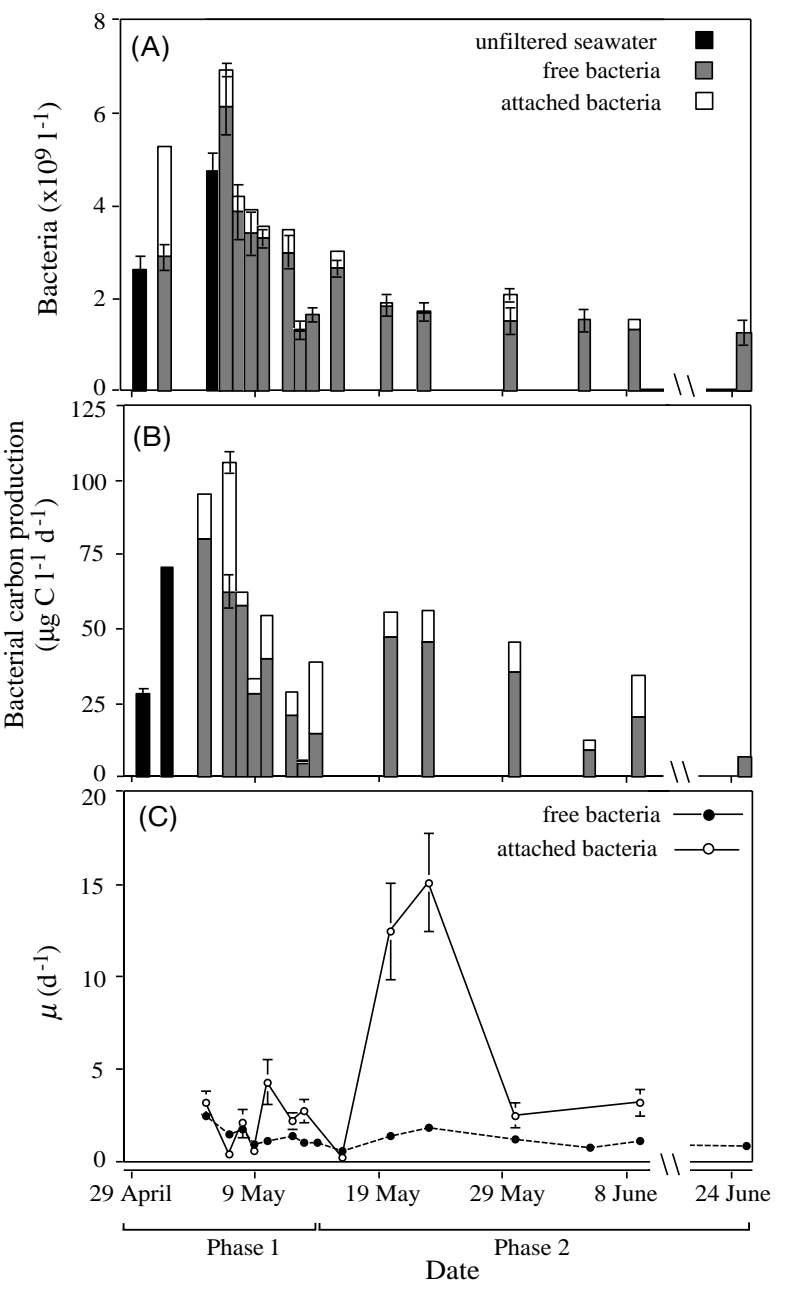

Fig. 2. (A) Bacterial abundance, (B) bacterial carbon production, and $(C)$ bacterial-specific growth rate $(\mu) \pm$ SD during the course of the bloom. Error bars, where not seen, are too small to be observed on the figure

cell count. The specific growth rate $(\mu)$ of attached bacteria (range: 0.3 to $15.1 \mathrm{~d}^{-1}$ ) was generally higher and was more variable than that of free bacteria (range: 0.7 to $1.9 \mathrm{~d}^{-1}$ ). The peak in attached bacterial $\mu$ occurred during the post-bloom period in Phase 2 was coincident with major changes in bacterial community $16 \mathrm{~S}$ rDNA composition and the maximum value for DOC.

\section{Enzyme activities}

Total enzymatic activities were highest during Phase 1 and decreased approximately an order of magnitude with the decline in chl $a$ and POC (Fig. 3A). Alpha-glucosidase activity (data not shown) followed the general pattern of $\beta$-glucosidase activity, but at lower cell-specific hydrolysis rates ( 0 to 25.6 and 0 to $6.1 \mathrm{amol} \mathrm{cell}^{-1}$ $\mathrm{h}^{-1}$ in the free and attached fractions, respectively). In general, more than $70 \%$ of total enzymatic activity was in the particulate fraction and ranged from 0 to 37,0 to 33 , and 0 to $6861 \mathrm{amol} \mathrm{cell}^{-1} \mathrm{~h}^{-1}$ for alkaline phosphatase, $\beta$-glucosidase and protease activities, respectively (Fig. 3B-D). Maxima in attached enzyme activities occurred at the peak of the bloom, with minor secondary peaks in $\beta$-glucosidase and protease activities coinciding with the peaks in attached $\mu$ and DOC during Phase 2. Cell-specific activities for alkaline phosphatase and protease were lower overall in the

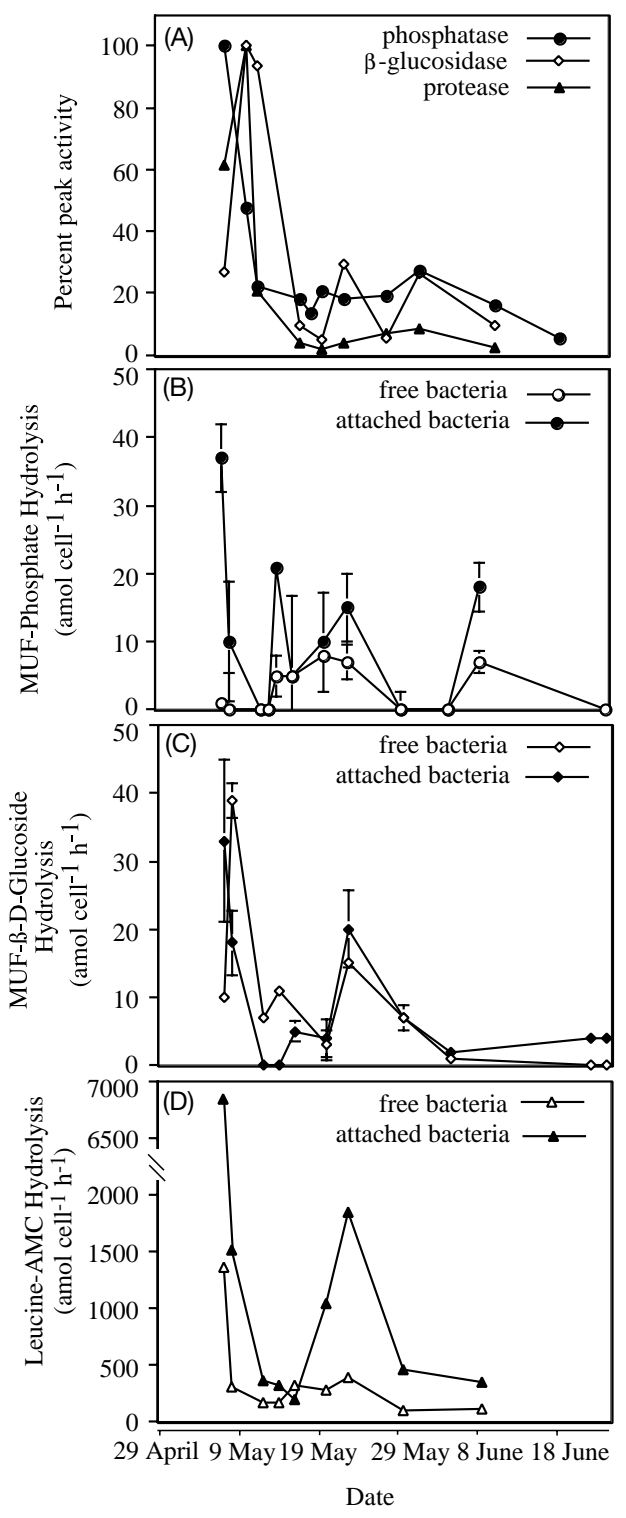

Fig. 3. Bacterial hydrolysis of leucine-AMC, MUF- $\beta$-glucoside, and MUF-phosphate representing protease, $\beta$-glucosidase and phosphatase activities, respectively. (A) Protease, $\beta$-glucosidase and phosphatase activities as the percent of their peak activities during the bloom; cell-specific hydrolysis of (B) MUF-phosphate \pm SD, (C) MUF- $\beta$-glucoside \pm SD, and

(D) leucine-AMC $\pm \mathrm{SD}$, for free and attached bacteria 
free-living phase, corresponding to 0 to 0.8 and 0 to 40 amol cell ${ }^{-1} \mathrm{~h}^{-1}$, respectively. Cell-specific $\beta$-glucosidase activity was higher in the free $(0$ to 39 amol cell $\left.{ }^{-1} \mathrm{~h}^{-1}\right)$ rather than the attached fraction $(0$ to 33 amol cell ${ }^{-1} \mathrm{~h}^{-1}$ ).

\section{Bacterial community structure}

DGGE analyses of $16 \mathrm{~S}$ rRNA gene fragments revealed 19 to 20 and 10 to 12 easily resolvable bands in the free and attached communities, respectively. These 16S rDNA banding patterns were highly reproducible and repeatable between gels and PCRs; representative gels of the free and attached size fractions are shown in Fig. 4. Some degradation of the DNA isolated on 25 June from the $<1.0 \mu \mathrm{m}$ fraction was apparent upon DGGE analysis and it is possible that only a subset of bands may be visualized for this sample. For this reason, this sample was omitted from all subsequent analyses (Fig. 4A, Sample 7).

Twenty-four bands were excised from the gels, cloned and sequenced. Of these, 17 clustered with the $\alpha$ - and $\gamma$-subclasses of the Proteobacteria and the Cytophaga phylogenetic groups (Fig. 5). Three of the sequences were related to rRNA genes from oxygenic phototrophs (chloroplasts and cyanobacteria). Two additional cloned amplicons were found to be heteroduplexes while another was a potential chimera and these were excluded from further analyses. All but 5 phylotypes reported in this study (SCR3, SCR11, ATT3, ATT4 and ATT6; see Table 1) belonged to phylogenetically undescribed species (<98\% identity with rRNA gene sequences of known species). The sequence of SCR3 was identical to that of the free-living clone FL1 isolated by DeLong et al. (1993) and ATT6 was 98\% identical to a Synechococcus sequence (Britschgi \& Giovannoni 1991) from a Pacific Ocean clone library. Two of the attached phylotypes related to Cytophaga were most similar (90 and $94 \%$ ) to 2 clones isolated from aggregates by DeLong et al. (1993).

We found that the majority of $16 \mathrm{~S}$ amplicons (bands) persisted through time but large changes in 16S rDNA banding patterns (estimated by density analysis) were observed on relatively short time scales. Cluster analysis of the banding patterns revealed that the most pronounced shift occurred between Samples 4 and 5, the period delimiting Phases 1 and 2 (Fig. 4). Between these sampling time points, the brightness of 3 DGGE bands in the $<1.0 \mu \mathrm{m}$ fraction decreased by $50 \%$. Two of these contained 16S rDNA amplicons related to Cytophaga (Bands 4 and 6; Table 1), and a third band contained an amplicon related to a member of the $\alpha$ Proteobacteria sub-phylum (Band 10). At the same
(A)
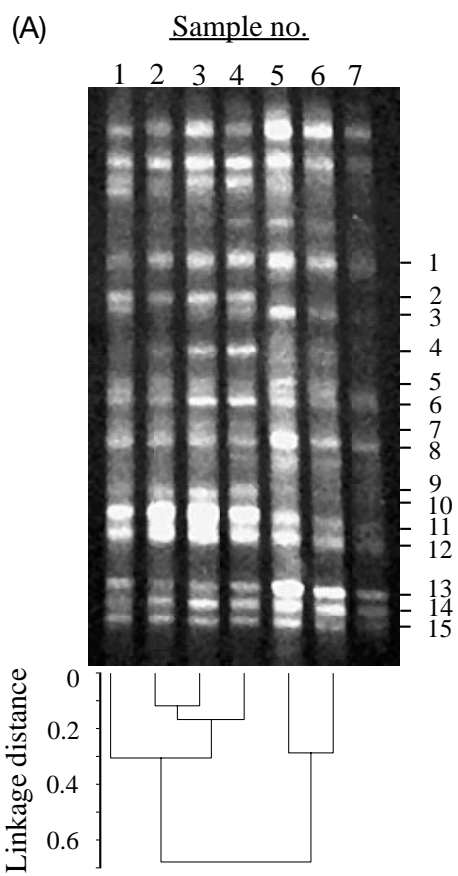

(B) Sample no.

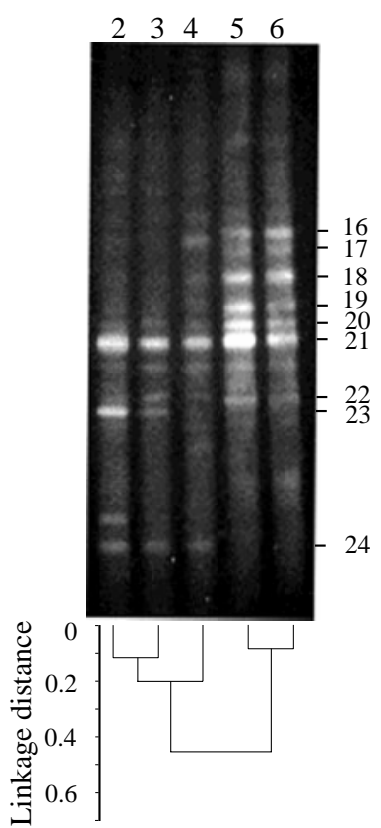

Fig. 4. DGGE profiles of 16S rRNA gene fragments from the (A) freeliving, and (B) attached bacterial communities. Samples 1 to 7 correspond to the sampling dates: 5 May, 7 May, 9 May, 13 May, 30 May, 9 June, and 25 June. Each band analyzed in this study is numbered and sequence information obtained from these bands is given in Table 1. Cluster analysis (UPGMA) dendrograms showing the relationship of the samples (lanes) in each DGGE gel are shown below the gel images. Sample 7 was omitted from cluster analysis due to probable degradation of the DNA

time, the brightness of 2 bands increased. These contained amplicons related to a Cytophaga (Band 8) and a $\gamma$-proteobacterium (Band 13). Obvious changes were also observed on even shorter ( 2 d) time scales, for example, the $135 \%$ increase in the staining intensity of Band 4 between the 7 to 9 May samples (Fig. 4, Samples 2 and 3). Only minor changes in the staining intensity of other bands were detected between these time points. In the attached fraction, some bands (16, 17, 23 and 24) were detectable only during Phase 1 or Phase 2, but not during both periods (Fig. 4B). The transition between the 2 bloom phases was also marked by large increases in the staining intensity of bands containing sequences related to a Cytophaga (Band 20) and plastids (Bands 18 and 19), and by the disappearance of a band containing Roseobacterrelated sequences (Band 24).

Although the timing of major changes in both free and attached $16 \mathrm{~S}$ rDNA composition appear to roughly coincide, no common 16S rDNA sequences, obtained from DGGE bands, were detected in the 2 consortia. 16S rDNA sequences obtained from Bands 1 and 17 differed from each other by $9 \mathrm{bp}$ although both were 


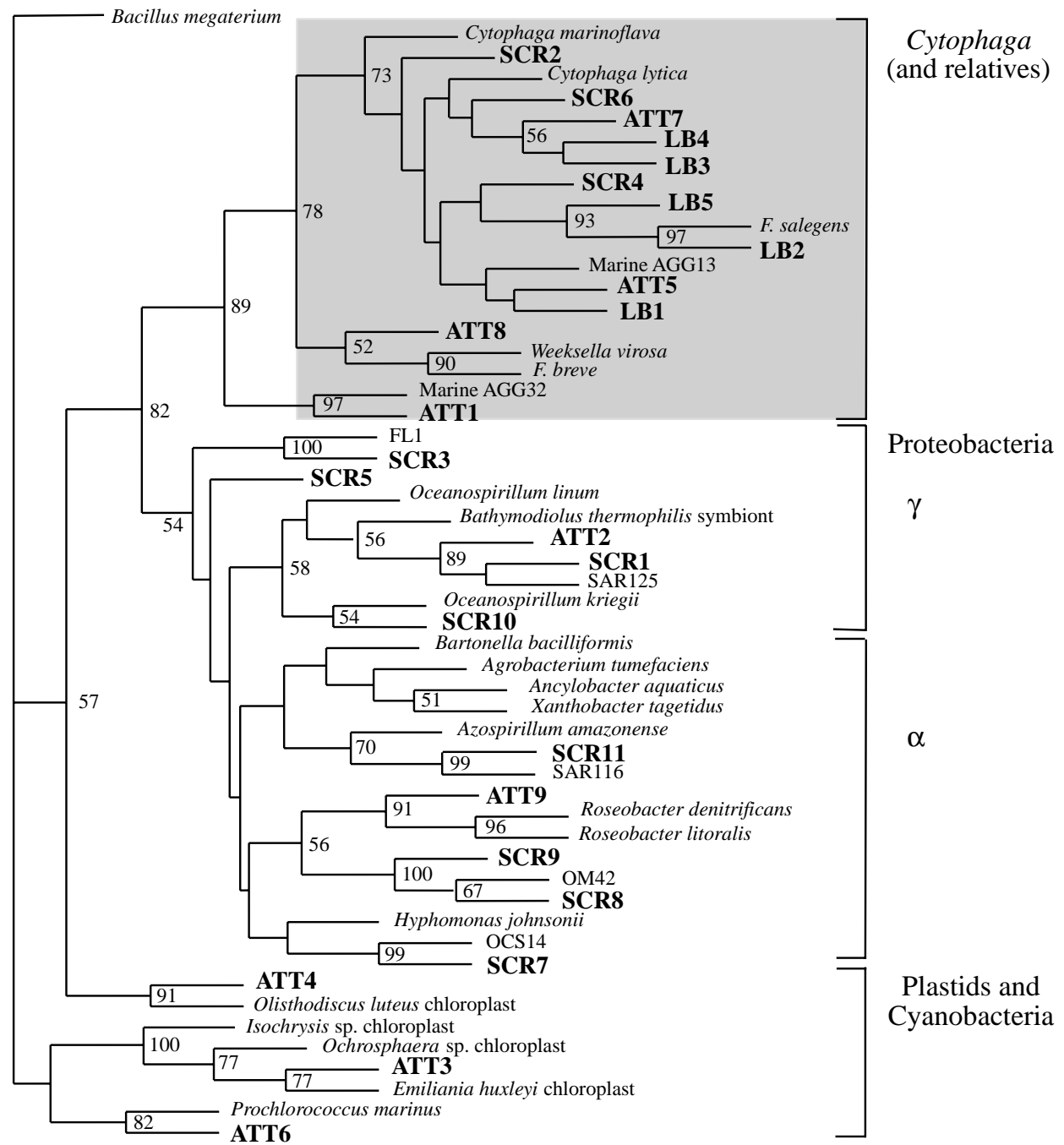

$10 \mathrm{bp}$

most similar to a cloned sequence (SAR125) related to the $\gamma$-subclass of the Proteobacteria (Mullins et al. 1995; Table 1). Sequences from Bands 11 and 15 were identical and these were assigned the same clone name (SCR9). SCR9 and ATT9 (particle-associated) were most similar to a Roseobacter; however, these differed from each other at 18 bases.

Sequences clustering in the Cytophaga group comprised two-thirds of the heterotrophic bacterial sequences in the attached fraction and approximately one-fourth of those in the free fraction. Using the Cytophaga group as a representative of the strains detected using the culture-independent approach, we screened our isolates to determine whether there was an overlap with culturable CLB. The 8 isolates (12\% of total screened) identified as members of this group were determined by DGGE to consist of 5 different phylotypes. The percent identities between the $16 \mathrm{~S}$
Fig. 5. Phylogenetic tree showing the relationships among all 16S rDNA clones and Cytophaga isolates obtained during the bloom in relation to representatives of bacterial and plastid rRNA genes. A shaded box encompasses the CytophagaFlavobacterium phylum. This tree was inferred by DNAdist and neighbor-joining methods (Phylip version 3.5) using 191 aligned bases beginning at the equivalent to base 341 (Escherichia coli numbering system). The tree is unrooted with a gram-positive bacterium (Bacillus megaterium) as the outgroup. The clones sequenced in this study are in bold; ATT1-9 and SCR1-11 are from attached and freeliving bacterial community samples, respectively, and LB1-5 are sequences obtained from Cytophaga isolates. Bootstrap values $>50 \%$ are indicated. The bar indicates nucleotide substitutions per $10 \mathrm{bp}$
rDNA sequences of the Cytophaga group isolates and the Cytophaga-related DGGE-PCR products ranged from 80 to $94 \%$.

\section{DISCUSSION}

Blooms of phytoplankton are common off the Southern California coast during the spring and are typically associated with changes in SST and vertical nutrient profiles (Eppley et al. 1978). These events can provide massive inputs of organic matter into coastal waters, triggering a dynamic response in the bacterial community characterized by large increases in cell number, secondary production, enzymatic activities, and growth rates. Mechanisms controlling variations in bacterial metabolism at different stages of a bloom, however, are poorly understood. Recent mesocosm studies examined 
the response of the bacterial community to substrate enrichment (Pinhassi et al. 1999, Riemann et al. 2000). A primary aim of these studies was to elucidate whether substrate induction or differences in bacterial community composition was responsible for observed changes in bacterial metabolism under different enrichment conditions. Addition of bovine serum albumin (BSA), for example, stimulated a 14 -fold increase in protease activity that was closely coupled to changes in bacterial community composition and the rapid growth of individual bacterial types (Pinhassi et al. 1999). In that study, 1 isolate demonstrated a net growth rate $\left(1.6 \mathrm{~d}^{-1}\right)$ over a $2 \mathrm{~d}$ period, a rate approximately 5 times faster than community turnover times. Our results suggest that similar concerted changes in bacterial metabolism and community structure also occur under the conditions of organic matter enrichment associated with natural algal blooms.

We hypothesized that changes in the phylogenetic composition of the bacterial community were at least partly responsible for changes in bacterial carbon dynamics. Overall, bacterial abundances and rate processes followed fluctuations in chl $a$ and were of a similar magnitude to those values reported for natural and experimental mesocosm blooms (Karner \& Herndl 1992, Middelboe et al. 1995, Smith et al. 1995). The period between 13 and 30 May was associated with increases in the activities of all ectoenzymes (with the exception of phosphatase) and an increase in the per cell growth rate of attached bacteria, presumably due to enhanced solubilization and uptake of organic material. During this time, DGGE profile analysis indicated a marked shift in the phylogenetic composition of the bacterial communities.

Rapid growth of specific bacterial types may explain the changes in DGGE banding patterns and, by inference, bacterial community structure. As in the Pinhassi et al. (1999) study, we found that rapid shifts in bacterial community composition occurred over a short time frame, e.g. the increases, of up to $135 \%$, in intensity of several bands bearing amplicons related to Cytophaga taxa. Cytophaga are known to be important degraders of biomacromolecules (Christensen 1977), and it is possible that different genotypes were physiologically better able to utilize labile organic material available at different stages of the bloom, giving rise to the changes in community structure observed by DGGE. Although it is not always possible to predict physiology simply based on phylogenetic affiliation, these results are consistent with the hypothesis that changes in bacterial community metabolism and growth are related to changes in species composition. However, additional per-cell changes in bacterial community metabolism are also likely.

Shifts in the composition of both the attached and free-living communities occurred during the same period even though the compositions of these 2 communities appeared to be distinct. We found that none of the genotypes identified co-occurred at detectable levels in both assemblages, in support of previous reports (DeLong et al. 1993, Weiss et al. 1996) that microbial consortia associated with particles differ from those in the free-living phase. Plastid and cyanobacteria sequences were found only in the attached fraction, although this was not surprising as the relatively large size of eukaryotic phytoplankton and cyanobacteria would cause most of these organisms to be trapped by the glass fiber pre-filter. BetaProteobacteria were not detected in this study although they have been found in other coastal marine environments (Rappé et al 2000) and predominate in freshwater assemblages (Weiss et al. 1996, Glöckner et al. 1999).

Phylotypes related to the $\alpha$ - and $\gamma$-Proteobacteria and members of the Cytophaga group occurred in free and attached communities with distinct types in each fraction. Alpha- and $\gamma$-Proteobacteria were represented by 4 clones each in the $<1.0 \mu \mathrm{m}$ and 1 clone each in the $>1.0 \mu \mathrm{m}$ size fractions. The greater phylotype richness and predominance of members of these groups within bands from the free-living fraction is constistent with previous analyses of bacterial consortia (DeLong et al. 1993, Acinas et al. 1999). In contrast, the occurrence of CLB in both size fractions was unexpected since a previous study indicated that they may be predominantly particle-specialists (DeLong et al 1993). In accordance with their hypothesized particlespecialist role, these organisms are known to have a high degradative capacity and are thus potentially major contributors to the degradation of organic particles. Since the bacterial carbon demand of attached bacteria is low (Smith et al. 1992), much of the hydrolysate released from aggregates is in the polymeric form and the transition of polymers to monomers is likely mediated by free-living bacteria. Cottrell \& Kirchman (2000) found that, in marine waters, free-living $\alpha$-Proteobacteria (and to a lesser extent $\gamma$-Proteobacteria) play a disproportionate role in the uptake of amino acids. In contrast, members of the Cytophaga group were important agents of polymer degradation, but not monomer consumption. While we did not specifically address the ecological roles of any of these groups, our results are consistent with the proposed particle and polymer-specialist roles for CLB. Further, these results suggest that under conditions of intense polymer and particle enrichment expected during phytoplankton blooms, the degradative action of CLB pervades throughout the polymeric and suprapolymeric (i.e. particulate) organic matter field.

In an attempt to physiologically characterize a dominant CLB strain, a Cytophaga-group probe was used 
to examine 67 bacterial isolates that encompassed a spectrum of colony morphologies cultured during the bloom. Consistent with previous observations that culturable bacteria are not necessarily representative of the dominant types in situ (Suzuki et al. 1997), none of the 16S rRNA gene sequences from cultured CLB matched those identified by DGGE. We further compared all of our 16S rDNA sequences to those of 30 sequences from isolates collected in this same region by Pinhassi et al. (1997). Two of our Cytophaga isolate sequences, but none of our cloned rDNA sequences, were identical to isolate sequences obtained by Pinhassi et al. (1997). Placement of all 16S rRNA gene sequences on a phylogenetic tree showed that free and attached CLB do not represent phylogenetically distinct lineages (Fig. 5). This agrees with results from the phylogenetic analysis of free and attached members of this phylum prepared by Crump et al. (1999) using estuarine, river, and coastal ocean rDNA libraries. However, we note that the length of the 16S rDNAs obtained in our study was only ca $191 \mathrm{bp}$; thus, only limited phylogenetic information could be obtained and bootstrap values were low overall. This is especially true for the sequences related to Cytophaga, probably due to the limited sequence information available in the database for this group.

In our sampling of DGGE bands, we found a higher diversity of bacterial phylotypes in the free-living community than in the attached community. This observation contrasts with the results of previous studies (DeLong et al. 1993, Rath et al. 1998), possibly due to PCR/DGGE-related artifacts, or to real differences in bacterial colonization of phytodetritus in these waters. If the DGGE banding patterns are a reasonable indicator of phylogenetic diversity, our results suggest that marine phytodetritus supports the rapid growth and dominance of a few specific colonizers. However, total species diversity in these samples is still unknown.

Consistent with previous reports that marine particles may serve as 'activity hotspots' (Smith et al. 1992, Azam 1998), we found that attached bacteria, on average, comprised $10 \%$ of the total population but accounted for nearly one-quarter of total integrated bacterial carbon production. Previous reports (Smith et al. 1995, Riemann et al. 2000) found an increase in attached bacterial numbers during the later stages of bloom development, due to the increased colonization of particles. The reason for consistently low numbers of attached bacteria seen during this versus other studies is not known. However, the extent of bacterial colonization of phytodetritus may depend on the quality and source of available particulates. Low numbers of attached bacteria in this study (vs mesocosm experiments) may also be due to the lower accumulation of aggregates due to transport. Bacterial loss was not specifically measured in this study although we calculate from abundance and integrated BCP that 76 to $140 \%$ of the attached bacterial population and 86 to $136 \%$ of the free-living population was lost during the 7 wk sampling period. Potential loss mechanisms include viral lysis, flagellate predation, and horizontal and/or vertical transport out of the study area. The selective loss of specific bacterial types, for example, through lysis by narrow host range bacterial viruses, or the selective feeding of grazers, may also influence the rDNA patterns observed by DGGE.

This study was conducted in the field, and thus precluded determination of the factors influencing the observed coupling of phylogenetic and biochemical changes. This is currently a rather intractable problem, one partially overcome by mesocosm experiments, although such studies forfeit true in situ conditions. The observed link between changes in 16S rDNA DGGE banding patterns and bacterial activities is therefore strictly correlative. However, it is notable that recent experiments (Riemann et al. 2000) identified similar shifts in community structure and bacterial community metabolism during a mesocosm diatom bloom.

DGGE has recently become a common technique for analyses of bacterial population ecology and dynamics. However, as with other molecular approaches for culture-independent studies of microbial ecology, DGGE-based analyses suffer from inherent problems. Biases related to DNA extraction efficiency, rRNA gene copy number, PCR primer annealing efficiency and cloning have been reviewed by many authors (Reysenbach et al. 1992, Farrelly et al. 1995) and may misrepresent the diversity and/or relative abundance of certain taxa. For this reason, interpretation of DGGE gel images by density analysis provides only a semiquantitative understanding of bacterial population dynamics. Thus, changes in $16 \mathrm{~S}$ rDNA banding patterns between samples reveal information on the relative 16S rDNA composition of a given assemblage. However, changes in the density of single bands do not necessarily equate to changes in bacterial taxon abundance over time.

While it is likely that this study was affected by biases, we were careful to analyze our methodology at each step in order to limit the effects of artifacts. We found that the results obtained by PCR-DGGE were highly repeatable; PCR products amplified on different days and DGGE gels run with different denaturing gradients yielded the same relative banding patterns. Phylotypes from different gel lanes that aligned with each other by DGGE were excised and sequenced to confirm that these co-migrating bands were identical. Since it was previously found that rDNAs cloned from single excised bands may include contaminating 
amplicons (Riemann et al. 1999), we reamplified and realigned by DGGE all cloned 16S rDNAs with their original positions on the gel. This analysis, however, does not remove the possibility that different sequences with the same melting point might co-migrate within a gel lane. Since analyzing several 16S rDNAs per cloning event was impractical, we sequenced 2 different clones from each excised band. The PCR inserts of all clone pairs were the same, suggesting that while we may still have underestimated 16S rDNA diversity in these samples, band co-migration was not a major problem in this study.

In summary, our results show that concerted shifts in bacterial community composition and metabolism can occur in relation to changes in the trophic state of the ocean. We found that both the metabolism and composition of the free and attached communities were distinct, providing additional evidence of niche specialization. The activity of bacterial hydrolytic enzymes has been previously observed to have profound effects both in mediating the transition from POM to DOM (Smith et al. 1992) and potentially in maintaining the longevity of blooms by preventing cell aggregation (Smith et al. 1995). High cell-specific enzyme activities and growth rates in the attached phase were also found in this study and changes in these rate processes may be explained by changes in the composition of the bacterial community. The extent to which shifts in bacterial community structure underlie changes in bulk metabolic properties is, however, still uncertain. These data stress the need for studying the physiological ecology of the as yet unculturable dominant bacterial taxa by developing culture, or culture-independent, methods, so that the significance of their ecosystem roles may be determined.

Acknowledgements. We thank Dr Maura Manganelli for help with the measurements of DOC, Gerardo Toledo for advice on constructing phylogenies, and 2 anonymous reviewers for their comments on the manuscript. This work was supported by NSF grants (OCE 98-19603 and OPP 9530851) to F.A.

\section{LITERATURE CITED}

Acinas SG, Antón J, Rodríguez-Valera F (1999) Diversity of free-living and attached bacteria in offshore western Mediterranean waters as depicted by analysis of genes encoding 16S rRNA. Appl Environ Microbiol 65:514-522

Altschul SF, Gish W, Miller W, Myers EW, Lipman DJ (1990) Basic local alignment search tool. J Mol Biol 215:403-410

Azam F (1998) Microbial control of oceanic carbon fluxes: the plot thickens. Science 280:694-696

Bidle KD, Fletcher M (1995) Comparison of free-living and particle-associated bacterial communities in the Chesapeake Bay by stable low-molecular-weight RNA analysis. Appl Environ Microbiol 61:944-952

Britschgi TB, Giovannoni SJ (1991) Phylogenetic analysis of a natural marine bacterioplankton population by rRNA gene cloning and sequencing. Appl Environ Microbiol 57:1707-1713

Christensen PJ (1977) The history, biology, and taxonomy of the Cytophaga group. Can J Microbiol 23:1599-1653

Cottrell MT, Kirchman DL (2000) Natural assemblages of marine proteobacteria and members of the CytophagaFlavobacter cluster consuming low- and high-molecularweight dissolved organic matter. Appl Environ Microbiol 66:1692-1697

Crump BC, Armbrust EV, Baross JA (1999) Phylogenetic analysis of particle-attached and free-living bacterial communities in the Columbia River, its estuary, and the adjacent coastal ocean. Appl Environ Microbiol 65:3192-3204

DeLong EF, Franks DG, Alldredge AL (1993) Phylogenetic diversity of aggregate-attached vs. free-living marine bacterial assemblages. Limnol Oceanogr 38:924-934

Don RH, Cox PT, Wainwright BJ, Baker K, Mattick JS (1991) 'Touchdown' PCR to circumvent spurious priming during gene amplification. Nucleic Acids Res 19:4008

Eppley RW, Sapienza C, Renger EH (1978) Gradients in phytoplankton stocks and nutrients off Southern California in 1974-1976. Estuar Coast Mar Sci 7:291-301

Farrelly V, Rainey FA, Stackebrandt E (1995) Effect of genome size and rRNA gene copy number on PCR amplification of 16S rRNA genes from a mixture of bacterial species. Appl Environ Microbiol 61:2798-2801

Felsenstein J (1993) PHYLIP: phylogeny inference package. University of Washington, Seattle

Ferris M J, Muyzer G, Ward DM (1996) Denaturing gradient gel electrophoresis profiles of 16S rRNA-defined populations inhabiting a hot spring microbial mat community. Appl Environ Microbiol 62:340-346

Fuhrman JA, Azam F (1982) Thymidine incorporation as a measure of heterotrophic bacterioplankton production in marine surface water: evaluation and field results. Mar Biol 66:109-120

Fuhrman JA, Comeau DE, Hagström ^, Chan AM (1988) Extraction from natural planktonic microorganisms of DNA suitable for molecular biological studies. Appl Environ Microbiol 54:1426-1429

Giovannoni SJ, Rappé MS, Vergin KL, Adair NL (1996) 16S rRNA genes reveal stratified open ocean bacterioplankton populations related to the green non-sulfur bacteria. Proc Natl Acad Sci USA 93:7979-7984

Glöckner FO, Fuchs BM, Amann R (1999) Bacterioplankton compositions of lakes and oceans: a first comparison based on fluorescence in situ hybridization. Appl Environ Microbiol 65:3721-3726

Hoppe HG (1983) Significance of exoenzymatic activities in the ecology of brackish water: measurements by means of methylumbelliferyl-substrates. Mar Ecol Prog Ser 11: 299-308

Jespersen AM, Christoffersen K (1987) Measurements of chlorophyll-a from phytoplankton using ethanol as extraction solvent. Arch Hydrobiol 109:445-454

Karner M, Herndl GJ (1992) Extracellular enzymatic activity and secondary production in free-living and marinesnow-associated bacteria. Mar Biol 113:341-347

Kirchman D, K'Nees E, Hodson R (1985) Leucine incorporation and its potential as a measure of protein synthesis by bacteria in natural aquatic systems. Appl Environ Microbiol 49:599-607

Lee S, Fuhrman JA (1987) Relationships between biovolume and biomass of naturally derived marine bacterioplankton. Appl Environ Microbiol 53:1298-1303

Maidak BL, Olsen GJ, Larsen N, Overbeck R, McCaughey MJ, Woese CR (1997) The RDP (Ribosomal Database Pro- 
ject). Nucleic Acids Res 25:109-111

Manz W, Amann R, Vancanney M, Schleifer KH (1996) Application of a suite of 16S rRNA-specific oligonucleotide probes designed to investigate bacteria of the phylum Cytophaga-Flavobacter-Bacteroides in the natural environment. Microbiology 142:1097-1106

Martinez J, Smith DC, Steward GF, Azam F (1996) Variability in ectohydrolytic enzyme activities of pelagic marine bacteria and its significance for substrate processing in the sea. Aquat Microb Ecol 10:223-230

Middelboe M, Søndergaard M, Letarte Y, Borch NH (1995) Attached and free-living bacteria: production and polymer hydrolysis during a diatom bloom. Microb Ecol 29: 231-248

Mullins TD, Britschgi TB, Krest RL, Giovannoni SJ (1995) Genetic comparisons reveal the same unknown bacterial lineages in Atlantic and Pacific bacterioplankton communities. Limnol Oceanogr 41:148-158

Murray AE, Hollibaugh JT, Orrego C (1996) Phylogenetic compositions of bacterioplankton from two California estuaries compared by denaturing gradient gel electrophoresis of 16S rDNA fragments. Appl Environ Microbiol 62:2676-2680

Muyzer GE, De Waal EC, Uitterlinden AG (1993) Profiling of complex microbial populations by denaturing gradient gel electrophoresis analysis of polymerase chain reactionamplified genes coding for 16S rRNA. Appl Environ Microbiol 59:695-700

Page RDM (1996) TREEVIEW: an application to display phylogenetic trees on personal computers. Comput Appl Biosci 12:357-358

Pinhassi J, Azam F, Hemphälä J, Long RA, Martinez J, Zweifel UL, Hagström $\AA$ (1999) Coupling between bacterioplankton species composition, polulation dynamics, and organic matter degradation. Aquat Microb Ecol 17:13-26

Porter KG, Feig YS (1980) The use of DAPI for identifying and counting aquatic microflora. Limnol Oceanogr 25:943-948

Rappé MS, Vergin K, Giovannoni SJ (2000) Phylogenetic comparisons of a coastal bacterioplankton community with its counterparts in open ocean and freshwater systems. FEMS Microbiol Ecol 33: 219-232

Rath J, Wu KY, Herndl GJ, DeLong EF (1998) High phylogenetic diversity in a marine-snow-associated bacterial assemblage. Aquat Microb Ecol 14:262-269

Redalje DG (1983) Phytoplankton carbon biomass and specific growth rates determined with the labeled chlorophyll a technique. Mar Ecol Prog Ser 11:217-225

Rehnstam AS, Backman S, Smith DC, Azam F, Hagström ^̊ (1993) Blooms of sequence-specific culturable bacteria in the sea. FEMS Microbiol Ecol 102:161-166

Reysenbach AL, Giver LJ, Wickham GS, Pace NR (1992) Differential amplification of rRNA genes by polymerase

Editorial responsibility: James Hollibaugh, Athens, Georgia, USA chain reaction. Appl Environ Microbiol 58:3417-3418

Riemann L, Steward GF, Fandino LB, Campbell L, Landry MR, Azam F (1999) Bacterial community composition during two consecutive NE Monsoon periods in the Arabian Sea studied by denaturing gradient gel electrophoresis (DGGE) of rRNA genes. DSR 46:1791-1811

Riemann L, Steward GF, Azam F (2000) Dynamics of bacterial community composition and activity during a mesocosm diatom bloom. Appl Environ Microbiol 66:578-587

Sambrook J, Fritsch EF, Maniatis T (1989) Molecular cloning: a laboratory manual. Cold Springs Harbor Laboratory Press, Cold Spring Harbor, NY

Simon M, Azam F (1989) Protein content and protein synthesis rates of planktonic marine bacteria. Mar Ecol Prog Ser 51:201-213

Smith DC, Azam F (1992) A simple, economical method for measuring bacterial protein synthesis rates in seawater using ${ }^{3} \mathrm{H}$-leucine. Mar Microb Food Webs 6:107-114

Smith DC, Simon M, Alldredge AL, Azam F (1992) Intense hydrolytic enzyme activity on marine aggregates and implications for rapid particle dissolution. Nature 359: $139-142$

Smith DC, Steward GF, Long RA, Azam, F (1995) Bacterial mediation of carbon fluxes during a diatom bloom in a mesocosm. Deep-Sea Res 42:75-97

Sugimura Y, Suzuki Y (1988) A high-temperature catalytic oxidation method for the determination of non-volatile dissolved organic carbon in seawater by direct injection of a liquid sample. Mar Chem 24:105-131

Suzuki MT, Rappé MS, Haimberger ZW, Winfield H, Adair N, Strobel J, Giovannoni SJ (1997) Bacterial diversity among small-subunit rRNA gene clones and cellular isolates from the same seawater sample. Appl Environ Microbiol 63: 983-989

Teske A, Wawer C, Muyzer G, Ramsing NB (1996) Distribution of sulfate-reducing bacteria in a stratified fjord (Mariager Fjord, Denmark) as evaluated by most-probable-number counts and denaturing gradient gel electrophoresis of PCR-amplified ribosomal DNA fragments. Appl Environ Microbiol 62:1405-1415

Thompson JD, Higgins DG, Gibson TJ (1994) CLUSTAL W: improving the sensitivity of progressive multiple sequence alignment through sequence weighting, positions-specific gap penalties and weight matrix choice. Nucleic Acids Res 22:4673-4680

Weisburg WG, Barns SM, Pelletier DA, Lane DJ (1991) 16S ribosomal DNA amplification for phylogenetic study. J Bacteriol 173:697-703

Weiss P, Schweitzer B, Amann R, Simon M (1996) Identification in situ and dynamics of bacteria on limnetic organic aggregates (lake snow). Appl Environ Microbiol 62: 1998-2005

Submitted: July 18, 2000; Accepted: November 21, 2000 Proofs received from author(s): December 13, 2000 
